原 著

$$
\begin{aligned}
& \text { コリオリ刺激が起立に及洔す影響 } \\
& \text { 綿貫 浩 - }{ }^{1)} \text {-高橋 正紘 }{ }^{1)} \cdot \text { 池田 卓生 }{ }^{1)} \\
& \text { 泉 龍太郎 }{ }^{2} \cdot \text { 武岡 元 }{ }^{2)}
\end{aligned}
$$

\title{
The Influence of Coriolis' Stimulation upon Stance Regulation
}

\author{
Koichi Watanuki ${ }^{1)}$, Masahiro Takahashi ${ }^{1)}$, Takuo Ikeda ${ }^{1)}$, \\ Ryutaro Izumi ${ }^{2)}$, Hajime Takeoka ${ }^{2)}$ \\ 1) Department of Otolaryngology, Yamaguchi University School of Medicine \\ 2) Japan Space Utilization Promotion Center
}

To evaluate the influence of spatial orientation upon stance regulation, we gave Coriolis' stimulation to the subject standing on the turntable, and the findings were compared to those of eye movements.

Six healthy adult subjects were asked to wear goggles and stand on a force platform at the center of the turntable with legs together. They performed a forward head tilt (30 deg) while rotating at a constant velocity. Perturbations of body and eye movements were evaluated by shifts in the center of pressure and recordings by a CCD video camera, respectively.

Rotation velocity was increased by $15 \mathrm{deg} / \mathrm{sec}$. None of the subjects touched the handrail of the turntable at rotation velocities less than $30 \mathrm{deg} / \mathrm{sec}$. The center of pressure shifted to the left under clockwise rotation, and to the right under counterclockwise rotation. The direction of body perturbation resembled the direction of slow phase in induced nystagmus. The center of pressure shifted in the direction opposite to the physical force given to the head (Coriolis' force), that is, to the direction of transient movement of the spatial framework in the brain.

From the present study, it seems likely that spatial orientation plays an important role in regulating stance, and that posture is subjected to a simple rule, as eye movements are.

Key words: stance, Coriolis' stimulation, spatial orientation, the center of pressure

\section{はじめに}

起立など身体骨格系の動作の特徵として，多く の筋群や多様な神経ネットワークにより実現され る, といら複雑性がある。移動中, 絶兄ず足底支

1) 山口大学医学部耳鼻咽喉科学教室

2)（財）宇宙環境利用推進センター
持面に重心ベクトルを投影する制御原理について は，未だ有力な理論はない。

空間識に異常が起こると動摇病が誘発され，自 律神経症状と共に著しい平衡失調が観察される 1) 5)。日常動作が破綻なく遂行されるためには, 空間識（脳内に再現される一種の周囲空間座標） により動作の基本プログラムが瞬時に修正される 
可能性が考えられる6) 8)。

回転イス上で頭部を傾斜すると，奇妙な感覚と 眼球運動が誘発される（コリオリ刺激）。これは 被検者の頭の中に周囲の静止空間ではなく，回転 するイス上の空間が再現されているため，頭部の 傾斜により見かけ上の加速が加わるためである。

今回は，動作に及洁す空間識の影響を明らかに するため，新たに回転テーブルを作成した。この 装置を用いて起立中にコリオリ刺激を与光, 重心 移動执よび眼球運動を記録した。コリオリ刺激中 の眼球運動はすでに当教室の三浦9）が詳細に報告 しているので, 今回は主に重心移動について報告 する。

\section{方法}

1) 対象

対象は聴覚, 前庭機能に異常を認めず，下肢に 外傷の既往のない健康成人 6 名（男性 3 名, 女性 3 名）である。年齢は24歳から31歳で, 平均 26.8 歳であった。

\section{2 ) 装置}

本研究のために新たに回転テーブル（ユキエン ジニアリング製）を作成した（図 1 ）。本体は直 径 $100 \mathrm{~cm}$, 高さ $31 \mathrm{~cm}$, 重量 $85 \mathrm{~kg}$ で, 回転速度 を毎秒 7 度から 127 度の範囲で無段階に変速する ことができる。周囲にはドーナツ状の幅 $50 \mathrm{~cm}$ の踊り場を置さ，転倒を防止するため四方に手す りを設けた。回転中, 任意に加速や減速, 回転方 向の変更が可能である。

\section{3 ）手順}

回転テーブルの中心に重心動摇計を置き, その 上に被検者を起立させ, 赤外線 $\mathrm{CCD}$ カメラの組 み込まれたゴーグルを装着した。ゴーグルの使用 により被検者は完全な遮眼状態となった。両足を 接して起立させ，上肢を前胸部で腕組みする姿勢 をとらせた。

まず回転テーブルが静止した状態で, 頭部の直 立と前屈時で, 足圧中心と眼球運動を記録し, コ ントロールとした。次いで回転テーブルを回転さ せ定速に達した後, 最低60秒間の受動的回転負荷 を与えた。姿勢が安定し, 回転や移動の感覚（以 下，移動感覚と略）が消失したことを確認した 後, さらに30秒経過した時点で, 頭部を前方に約 30 度傾斜させた。姿勢が安定し, 移動感覚が消失 したことを確認するまで, 前屈姿勢を継続させ
た。頭部の前屈前後で足圧中心と眼球運動を記録 した。頭部の前屈動作を実験前に十分練習し，実 験中は側方よりビデオカメラで監視した。

回転速度を毎秒 15 度，30度，45度，60度，75度 の 5 段階に変えて, 回転方向を右回転と左回転に 変えて記録した。それぞれの実験の間には十分な 休息を与兄, その間に移動感覚, 自律神経症状に ついて問診した。

4 ）記録方法と結果の分析

a ）重心の移動

頭部直立中の 10 秒間と, これに引き続く頭部前 屈開始から10秒間の足圧中心を記録した。それぞ れの外周面積と動摇中心（X座標， $\mathrm{Y}$ 座標々れ ぞれに括ける全てのデータの算術的平均值, 動摇 平均中心とも(ら）を求め，その座標の移動方向 を重心の移動方向とした。

足圧中心の記録には重心動摇計（日本電気三栄

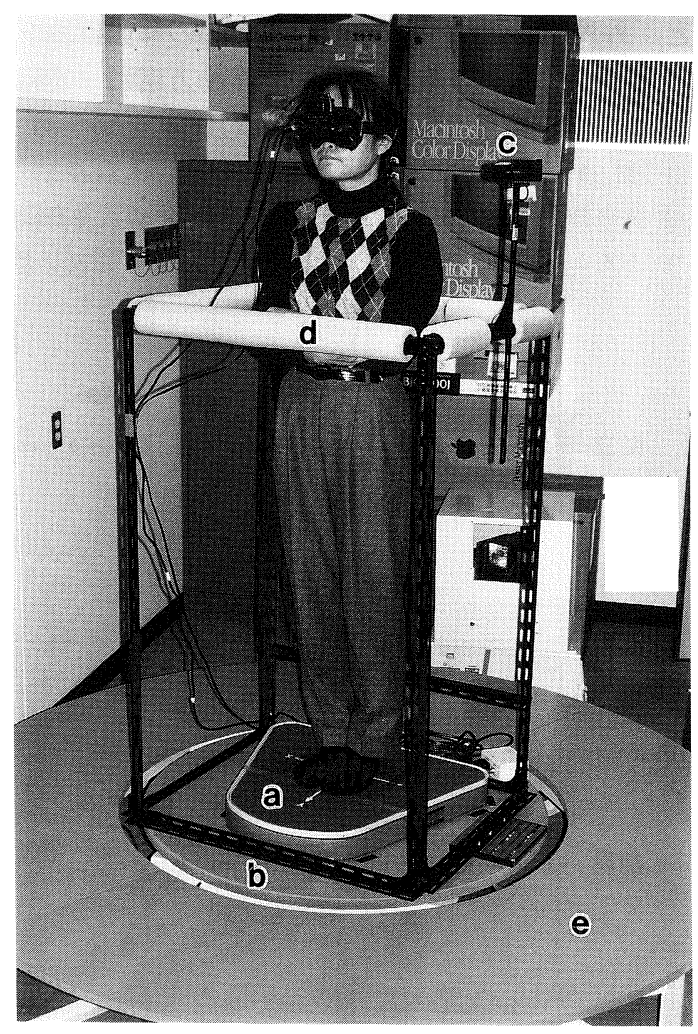

図 1 回転テーブル

a: 重心動摇計, b: 回転テーブル, c: ビデ オ・カメラ, $\mathrm{d}$ : 手すり, e: 踊り場 
1G06）を用いた。データの分析は解析プログラ ム（日本電気三栄 Statokinesigram No. 201）を 用い, 再生条件を10秒間1024ポイントに設定し た。検定は動摇面積と動摇中心（X, Y 座標別） について Wilcoxonの U 検定を用いた。

b ) 眼球運動

頭部直立扣よび前屈した時の眼球運動を, 赤外 線 CCD カメラを用いてビデオテープに記録し た。今回は画像から眼球の移動方向を定性的に求 めた。

c ）移動感覚括よび自律神経症状

実験中に口頭で問診し，その内容を詳細に記録 した。自律神経症状は Graybiel の分類 ${ }^{10111)}$ 飞準 じて, 嘔気, 唾液分泌充進, 意識レベル, 疼痛, 中枢神経症状について有無を確認し, 顔色, 発汗 状態を観察した。

\section{結果}

静止抢よび毎秒30度の回転に打ける足圧中心の 記録の一例を図 2 に示す。静止で頭部を前屈する と, 外周面積は増大するが動摇中心の移動はみら れなかった。他の被検者を含め移動方向に一定傾
向を認めなかった。

テーブルの右回転中に頭部を前屈すると, 外周 面積は増大し, 動摇中心は左方へ移動した。左回 転では同様に, 外周面積は増大し動摇中心は右方 へ移動した。

回転速度を毎秒15度刻みで毎秒15度, 30 度, 45 度，60度，75度と段階的に上げていったところ， 毎秒15度および30度の回転の前屈では全員が手す りに触れることもなかった。毎秒45度の回転では 1 名が手すりに触れたため実験を中止した。足圧 中心分布はびをん性に広がり, 起立を維持するの に必要な許容範囲を越えているのがわかる（図 3 )。さらに毎秒 75 度の回転では 3 名が手すりに 触れ，目的とする記録が得られなかった。最後ま で実験が可能であった 2 例も回転速度が上昇する に従って, 頭部前屈後の動摇は徐々に増大し, 毎 秒75度の回転では, 起立姿勢を保持するのも困難 な状態であった。

全被検者で記録の得られたのは毎秒 15 度と 30 度 の 2 つだけであった。今回は動摇のより大きな毎 秒30度の結果を分析した。

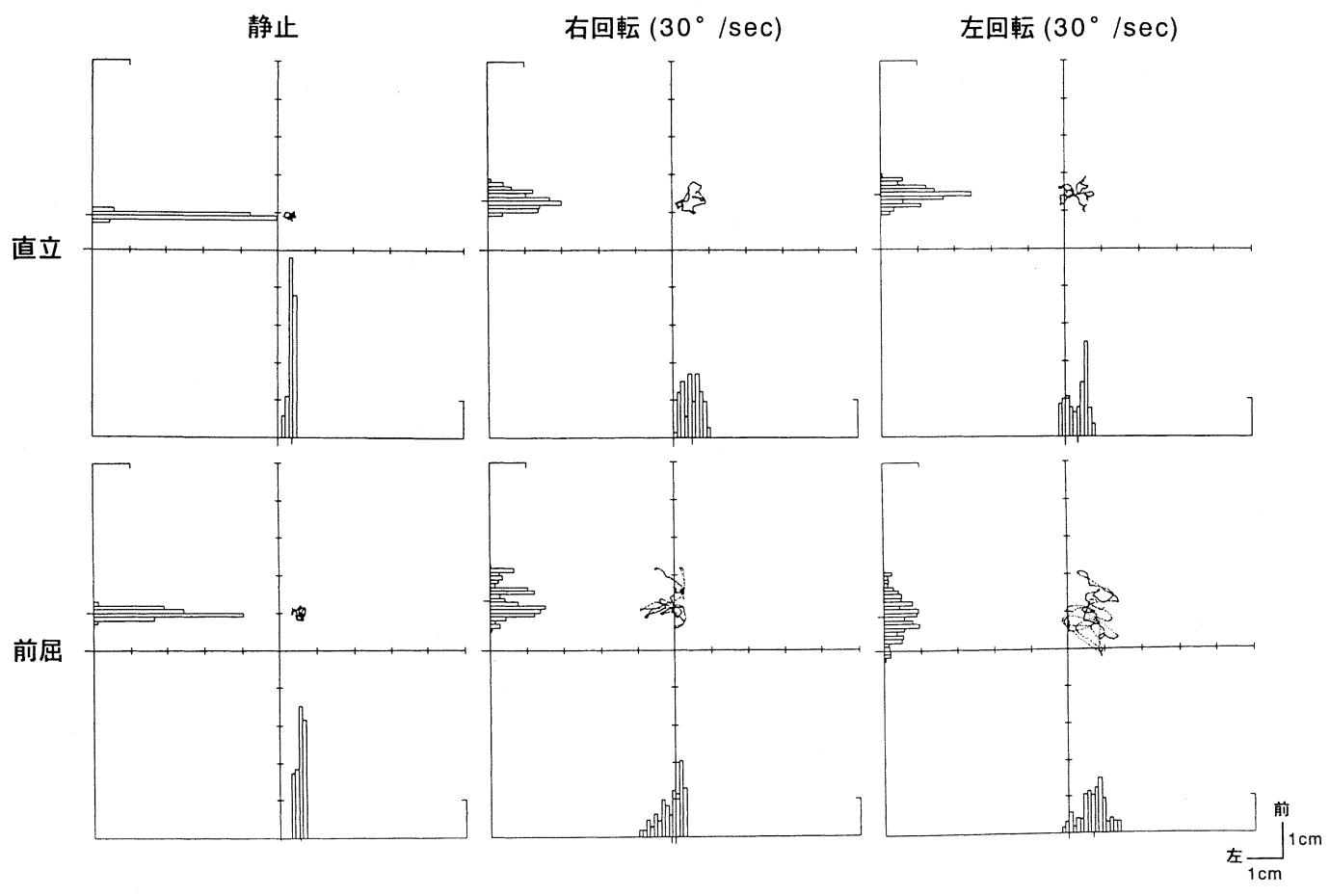

図 2 足圧中心の記録 
1 ）足圧中心の変化

頭部の前屈により, 外周面積は右回転, 左回転 ともに全例で増大し，有意の変化であった(図 4 , $\mathrm{p}<0.05)$ 。頭部を前屈すると, 動摇中心は全例

直立

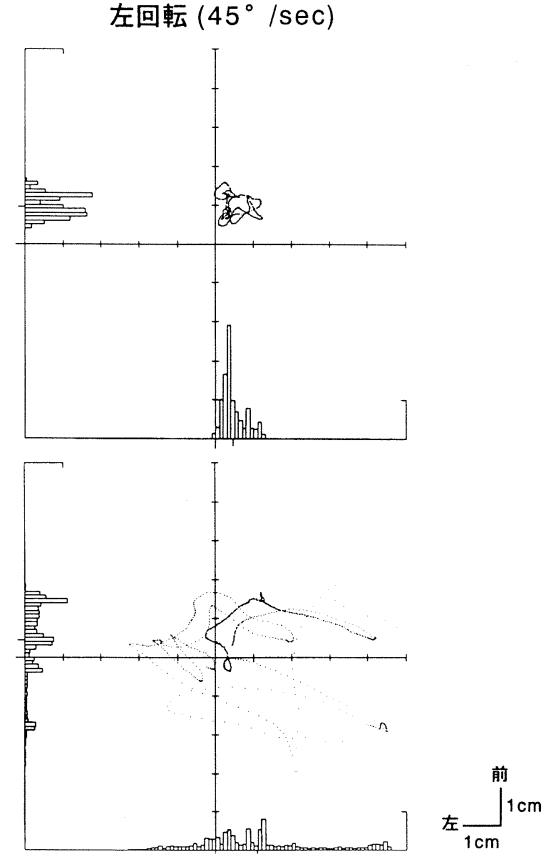

図 3 手すりに触れた例の足圧中心の記録

で右回転時には左方へ，左回転時には右方へ移動 し，統計学的に有意であった（図 $5 \mathrm{~A}, \mathrm{p}<0.05$ )。 前後方向への移動は一定傾向を示さなかった（図 $5 \mathrm{~B}, \mathrm{p}>0.1)$ 。

2 ) 眼球運動の変化

CCD ビデオ・カメラで記録した眼球運動の分 析では, 回転テーブルの右回転時には被検者側よ りみて時計方向の回旋性眼振を認めた。回転テー ブルの左回転では, 被検者側よりみて反時計方向 の回旋性眼振を認めた。

3 ) 移動感覚（表 1 )

移動感覚は被検者によって表現が異なるが，全 例とも回転テーブルが右回転では左方あるいは反 時計方向（前額面）へ，回転テーブルが左回転で は右方あるいは時計方向（前額面）への受動運動 感覚を訴えた。

4 ) 自律神経症状 (表 2)

1 名が軽度の発汗を, 2 名が軽度の胃部不快感 を訴光たが，他の 3 名は自律神経症状を示さなか つた。

\section{考察}

コリオリ刺激は動摇病を誘発する方法として, しばしば利用されてきている。その多くは回転イ スに座った状態の実験であり, 動摇病の感受性を 調べるためのものである。眼球運動も分析されて
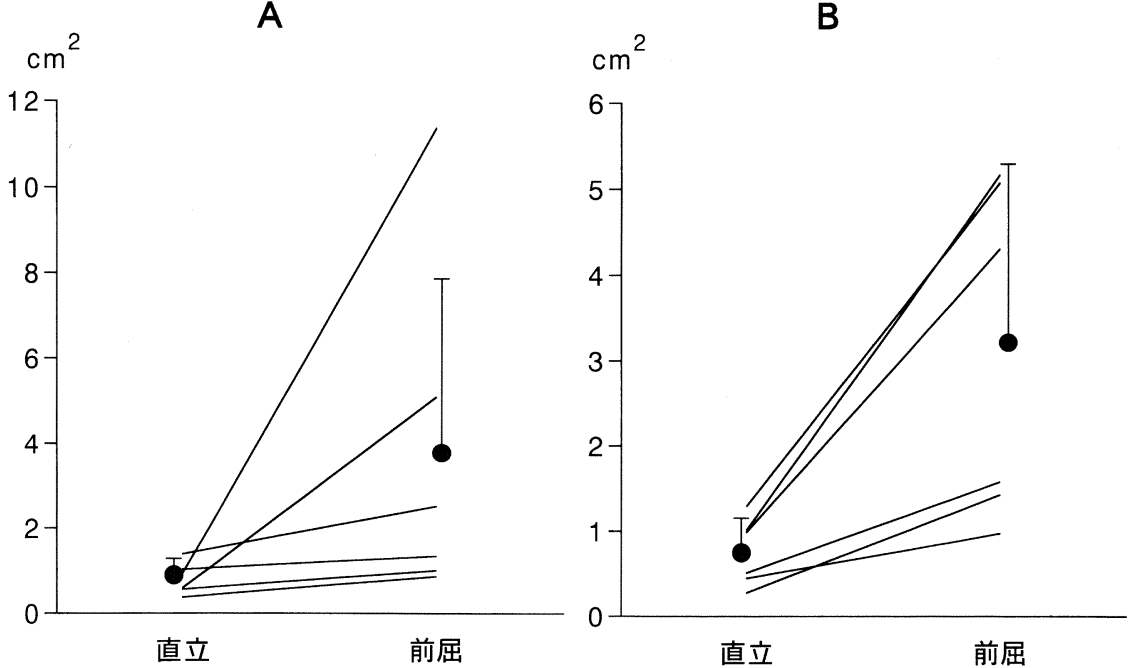

図 4 外周面積の変化

A: 右回転の結果，B: 左回転の結果を示す。黒丸は平均值，エラーバーは標準偏差を示す。 
Equilibrium Res Vol. 57(4)

A

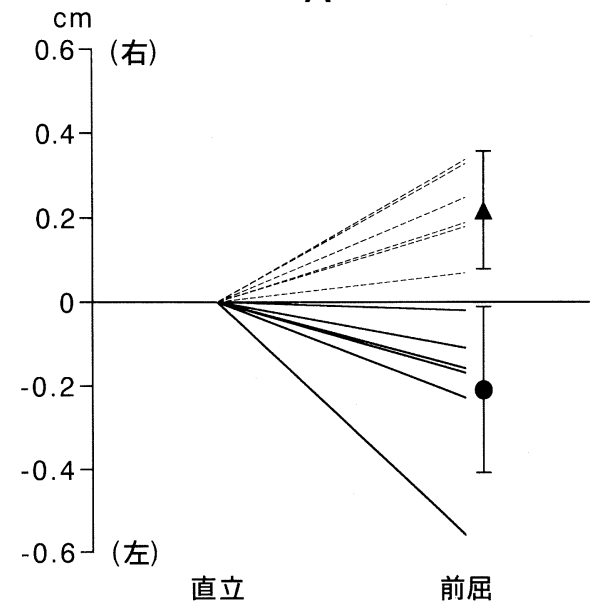

B

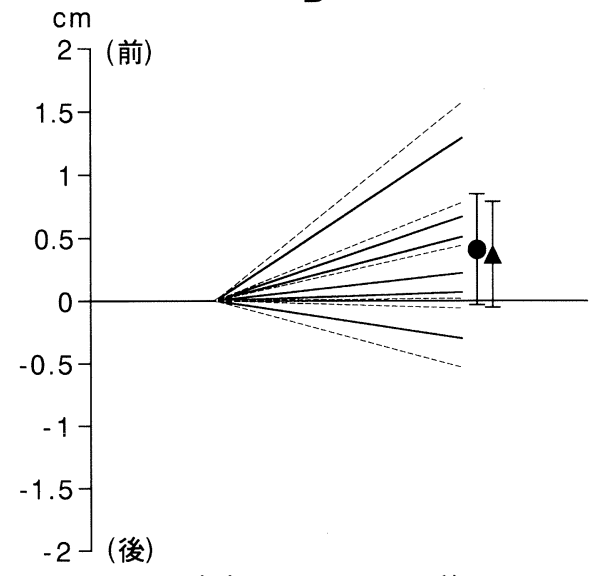

直立 前屈

図 5 動摇中心の変化

A: 左右方向の変化, B: 前後方向の変化を示す。実線拈よび黒丸は右回転での結果㧊よび平均値, 点線拉 よび黒三角は左回転での結果拉よび平均值, エラーバーは標準偏差を示す。

表 1 移動感覚

\begin{tabular}{|c|c|c|}
\hline 被検者 & 右回転 & 左回転 \\
\hline A & 左方へ & 右方へ \\
\hline$B$ & 左方へ & 右方へ \\
\hline C & 左下方へ & 右下方へ \\
\hline D & 左方 - 反時計方向(前額面)へ & 右方 - 時計方向(前額面)へ \\
\hline$E$ & 左方 · 反時計方向(前額面)へ & 右方 - 時計方向(前額面)へ \\
\hline $\mathrm{F}$ & 左方 · 反時計方向(前額面)へ & 右方 - 時計方向(前額面)へ \\
\hline
\end{tabular}

表 2 自律神経症状

\begin{tabular}{cll}
\hline 被検者 & 右回転 & 左回転 \\
\hline A & なし & なし \\
$B$ & なし & なし \\
$C$ & 胃部不快感 & 胃部不快感 \\
$D$ & 胃部不快感 & 胃部不快感 \\
$E$ & 軽度の発汗 & 軽度の発汗 \\
$F$ & なし & なし \\
\hline
\end{tabular}

いるが， CCD ビデオ・カメラによる観察はほと んど報告されていない。起立姿勢に及ぼす影響に ついては, Fitger, Brandt ${ }^{12)}$ がュリオリ刺激で姿 勢が不安定になることを報告している。しかし定 量的には分析されていない。
今回は回転テーブルを用いることにより，コリ オリ刺激が起立中の重心と眼球運動に与学影響 を同時に観察した。本実験は, 空間識が身体骨格 系と動眼系にどのよらに関わるか，を調べるのに 好都合である。

コリオリ刺激中に頭部に加わる力は, 角速度べ クトルを用いることで, 理論的に求めることがで きる(図 6 ）913)14。右方向に一定の速度で回転し ているときの頭部運動は, 右ネジの約束から， $\omega 1$ のよらな重力方向に一致した角速度ベクトルで表 すことができる。頭部を直立位から前屈すると, 空間的な回転運動は変化しないが，頭部を貫く角 速度ベクトルは $\omega 2$ のように変化する。これをべ クトルの合成として考えると, コリオリ刺激によ り $\Delta \omega$ のような角速度ベクトルの変化（角加速度 


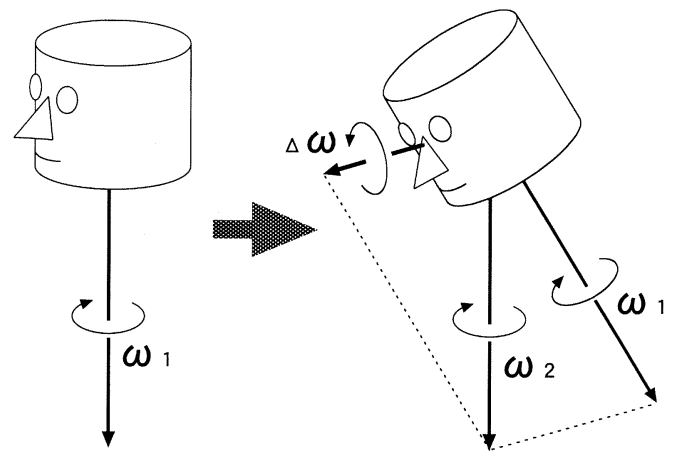

図 6 頭部前屈による角速度ベクトルの変化 $\omega 1$ : 頭部前屈前の角速度ベクトル， $\omega 2$ : 頭 部前屈後の角速度ベクトル， $\Delta \omega:$ コリオリ 刺激による角速度ベクトルの変化（角加速 度ベクトル)。

ベクトル）が生じたことになる。頭部を前屈する 前後の定速回転運動（角速度べクトル $=\omega 1, \omega 2)$ は, 定速であるため前庭器では知覚されない。こ の結果, コリオリ刺激によって生じる角速度べク トルの変化 $(\Delta \omega)$ のみが前庭器に知覚されるこ とになる。

コリオリの力は純粋に物理学的な力（慣性力） なので，頭部に直接作用するならば，その力の方 向に頭部が偏倚させられるはずである。つまり右 回転の前屈では頭部が右方に曲げられ, 重心も右 方に偏位するはずである。しかし今回の実験で は，全く逆の結果が得られた。

そこで高位中枢を含むニューラル・ネットワー クにより再現される自己と周囲空間の関係, つま り空間識の概念を想定することで，これらを単純 な現象として理解することが可能である。今回の 条件では, コリオリの力は意志的な前屈運動途中 で一瞬生じ, 受動的な移動は極めて小さかったと 考光られる。この結果, コリオリの力は頭部内の 前庭器を刺激し, 脳内の外界空間座標が影響され ることになる。つまり脳内の空間識は頭部に加わ る力とは逆の方向の運動を再現することになる。

テーブルが右方向に回転している時に頭部を前 屈すると, 脳内には被検者からみて反時計方向の 回旋運動（ローリング）が再現される。この空間 識に従って眼球運動は反時計方向に回旋する（眼 振緩徐相)。一方, 身体骨格系は, 足底とテーブ ルの摩擦が大きいので, 回旋運動とはならずに重
心が左方へ移動する。同様に，左回転の場合には 眼球運動は時計方向回転となり, 重心は右方へ偏 位する。さらに移動感覚も, 重心移動や眼球運動 の方向に一致していた。これより, 移動感覚は単 に空間識が大脳皮質に投影された結果とみること もできる。空間識の概念を用いることにより, 重 心の移動, 眼球運動抽よび移動感覚を同じ仕組み で説明することが可能であった。

姿勢の制御は, 多様な知覚和よび運動システム が複雑に関係しているが，単純な動作として統合 されている。ある外力が働いたとしても，それが 直接作用し, 姿勢変化として観察されるとは限ら ない。しかし今回の研究では, 起立や眼球運動 が，角速度ベクトルの変化として理論的に求まる 空間識を忠実に反映していることが判明した。こ れより, 身体骨格系も動眼系と同様に, 現在考光 られているよりも, 単純な原理で制御されている 可能性が示唆された。

今回の実験結果を, 従来の前庭眼反射あるいは 前庭脊髄反射の概念で説明することも, 現象的に は可能である。しかし，同じコリオリ刺激におい ても, 遮眼ではなく, 裸眼で周囲空間を認知でき る条件で行うと, 重心移動, 眼球運動, 移動感覚 は全く異なってしまう（未発表データ）。この条 件に打いても前庭器に加わる刺激は等しいのであ る。従来の考方方では視性反射による修飾で説明 するのであろらが，明確な結果を予想することは 困難であろら。

今回の実験条件には含まれなかったが，明所の コリオリ刺激に扣いても, 空間識の概念は有効で ある。今後, これらの実験条件を加えてさらに報 告する予定である。

\section{まとめ}

1 、新たに作成した回転テーブルを用いて, 健 康成人 6 名に起立中コリオリ刺激（頭部の前屈） を与え, 遮眼下で重心移動と眼球運動を記録し た。

2. 回転中の頭部前屈により, 足圧中心の外周 面積は増大し, 動摇中心が右回転では左方へ, 左 回転では右方へ有意に移動した。

3. 頭部前屈により, 右回転では被検者からみ て時計方向の回旋性眼振が，左回転では反時計方 向の眼振が誘発された。

4. 移動感覚は重心の移動方向や眼振緩徐相と 
一致する傾向が見られた。

5. 重心移動, 眼球運動, 移動感覚は全て, 空 間識の概念を用いることにより, 同じ仕組みで説 明することができた。

これらより, 身体骨格系統, 動眼系を問わず動 作は, 感覚と同様に, 脳内に再現された外界空間 に忠実に従うと言える。

本論文の要旨は, 第55回日本平衡神経科学会総 会（1996年，京都）に执いてロ演した。

本研究は宇宙開発事業団が推進している「宇宙 環境利用フロンティア共同研究」プロジェクトの 一環として行ったものである。

\section{文 献}

1) Takahashi M, Saito A, Okada Y, et al: Locomotion and motion sickness during horizontally and vertically reversed vision. Aviat Space Environ Med 62: 136-140, 1991

2) Takahashi M, Takei Y, Saito A, et al: Motion sickness and equilibrium ataxia. Aviat Space Environ Med 63: 486-490, 1992

3 ) Takahashi M, Toriyabe I, Takei Y, et al: Study on experimental motion sickness in children. Acta Otolaryngol (Stockh) 114: 231 $-237,1994$

4) Takahashi M, Ogata M, Miura M: Teleology of motion sickness. Acta Otolaryngol (Stockh) 115: 130-133, 1995

5 ) Ikeda T, Takahashi M: Active posture control during experimental motion sickness in guinea-pigs. Acta Otolaryngol (Stockh) 117: 815-818, 1997

6 ) 高橋正紘, 岡田行弘, 斎藤 晶, 他: 生体内
座標軸理論一空間認知による固視, 歩行の制 御. 日耳鼻 94: 198-202, 1991

7 ) 高橋正紘: 平衡制御に和ける空間認知の意 義. Equilibrium Res 51: 226-232, 1992

8 ) Takahashi M, Ogata M, Miura M: The significance of motion sickness in the vestibular system. J Vestib Res 7: 1-9, 1997

9 ) 三浦正子：コリオリ刺激で誘発される眼球運 動々動摇病症状の研究. Equilibrium Res 56: 338-346, 1997

10) Graybiel A, Wood CD, Miller EF, et al: Diagnostic criteria for grading the severity of acute motion sickness. Aerosp Med 39: 453455, 1968

11）斎藤 晶：逆転プリズム装着下自由歩行によ る動摇病の研究. 慶應医 68: 763-772, 1968

12) Fitger C, Brandt Th: Posturography of ataxia induced by Coriolis- and Purkinje-effects. Aviat Space Environ Med 53: 153-161, 1982

13) Guedry FE Jr, Benson AJ: Coriolis crosscoupling effects: Disorienting and nauseogenic or not? Aviat Space Environ Med 49: 29-35, 1978

14) Guedry FE Jr: Visual counteraction of nauseogenic and disorienting effects of some whole-body motions: A proposed mechanism. Aviat Space Environ Med 49: 36-41, 1978

$$
\left(\begin{array}{l}
\text { 原稿到着 : 平成 } 9 \text { 年 } 10 \text { 月 } 15 \text { 日 } \\
\text { 別刷請求先 : 綿貫浩一 } \\
\text { †755-8505 山口県宇部市小串 } 1144 \\
\text { 山口大学医学部耳鼻咽喉科学教室 }
\end{array}\right)
$$

